\title{
Sex change and female dimorphism in Calanus finmarchicus
}

\author{
Camilla Svensen*, Kurt Tande \\ Norwegian College of Fishery Science, University of Tromse, N-9037 Tromse, Norway
}

\begin{abstract}
Adult females were examined from November until spring in northern Norway $\left(70^{\circ} \mathrm{N}\right)$ to determine the fraction with the quadrithek and the fraction with the trithek setal pattern on the antennule. The quadrithek (Q) pattern is a male characteristic in which odd numbered, proximal segments carry 2 aesthetascs and 2 setae; the trithek (T) pattern has 1 aesthetics on all antennular segments. The frequency of quadrithek females $(\% \mathrm{Q}=100 \times[\mathrm{Q} / \mathrm{T}])$ varied with season. It peaked at $38 \%$ in February, declining to $25 \%$ in March. Higher proportions appeared early, consistently between years, i.e. higher proportions were found among the first females emerging from the stock of resting copepodids. In light of the hypothesis of Fleminger (1985; Mar Biol 88:273-294) that females with the quadrithek pattern result from sex switching by genetic males, we tested whether $\% Q$ in newly moulted females could be altered by separate exposure of the maturing CVs to adult males or females. The experiments were run. with specimens from Grøtsund during the last 3 wk prior to moulting of CVs in the field. Of females not exposed to adults as CVs, $35 \%$ had quadrithek patterns, while those exposed to adult males or females produced 33 and $37 \%$ quadritheks respectively. In these experiments, presence of adult Calanus finmarchicus (Gunnerus) did not influence the proportion of females with male characteristics. No evidence for sex specific pheromones was found and therefore the stimulus for sex change was not revealed. A possible influence of the environment on C. finmarchicus sex determination (ESD) is suggested and discussed.
\end{abstract}

KEY WORDS: Sex change - Dimorphism - Copepods - Environmental sex determination (ESD)

\section{INTRODUCTION}

Fleminger (1985) described female dimorphism as a phenomenon occurring in most populations of copepods in the family Calanidae. The dimorph female, 'quadrithek', expresses the male phenotype in the number and arrangement of aesthetascs on the antennules, in contrast to the 'normal' trithek females, while the rest of the characteristics are female in all respects. Based on this described female dimorphism, Fleminger postulated a sex change, suggesting that quadrithek females originate from the largest genotypic CV males, in which the gonad develops as an ovary.

There must be an adaptive value for the quadrithek female that compensates for the cost of changing sex, and both timing and correlation between fecundity and body size seem to be important in this respect. As a result of the males emerging first from diapause, there will

•E-mail: camillas@nfh.uit.no be a short period with an excess of males. Males with the opportunity to change sex could then gain an advantage if their offspring are in the majority at the end of the breeding season (regardless of generations). On the other hand, when there is an excess of females in the population, it is an advantage to be a male during reproduction, since males will have the opportunity to contribute genetically to the eggs of many females. Males changing sex under this circumstance would only gain the advantage of having a larger size than average females. Larger size results because male CVs are larger than female CVs, while switching they increase by the greater $\mathrm{CVI} / \mathrm{CV}$ ratio that operates for females. In this paper we demonstrate that there are 2 significantly different size-groups of females, supporting the theory that 1 of these could be sex-switched males.

After a detailed analysis of female dimorphism, Fleminger postulated 3 working hypotheses: (1) that the sex determination in calanid copepods is mainly but not exclusively under genetic control; (2) that envi- 
ronmental factors can induce sex change from CV potential males to functional females; and (3) that the formation of secondary sexual characteristics is a response to hormones (i.e. 'androgenic-like secretions from the genital tract'), which probably is related to the gonads or gonaducts, a process believed to resemble the sexual morphogenesis found in Malacostraca (Charniaux-Cotton 1960, 1962).

The study we report was intended to test Fleminger's hypothesis that quadrithek females are sex-switched males. Our main objective was simply to check whether sex change occurs in Calanus finmarchicus (Gunnerus) or not. Work included a field study comparing frequencies of quadrithek females over a latitudinal range, and a simple manipulative experiment. The experiment tested the possibility that the sex at maturation after the $\mathrm{CV}$ resting phase could depend upon the sex of individuals already matured around them and emitting signals of their presence and gender. We assumed those signals would be pheromones and designed the experiment accordingly. The test individuals were sampled from a population in a North Norwegian fjord, since the annual generation cycle found here facilitates a distinct separation in time between the various reproductive and developmental phases.

\section{MATERIALS AND METHODS}

Field work. The first test was based on 2 November to April time-series collected in 2 successive years (1993/1994 and 1994/1995) from Grøtsund. Northern Norway (Fig. 1). The sampling station is located north-
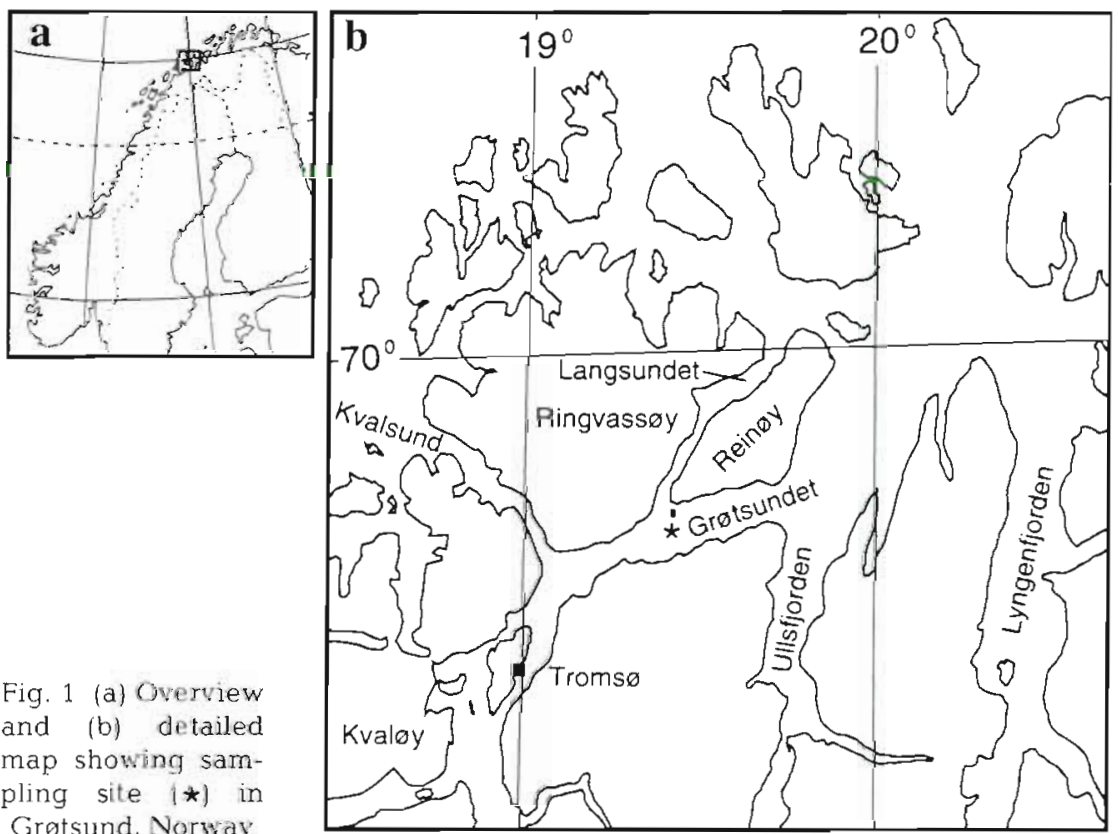

Fig. 1 (a) Overview and (b) detailed map showing sampling site $(*)$ in Grotsund, Norway east of Troms $ø$ at $69^{\circ} 47^{\prime} \mathrm{N}, 19^{\circ} 13^{\prime} \mathrm{E}$, where the Norwegian coastal current protects Grotsund from the strong influence of Atlantic waters, although the coastal water can be influenced by several adjacent sounds. The mean depth is about $100 \mathrm{~m}$, and the samples were collected in the deepest region of the sound at approximately $200 \mathrm{~m}$. The monthly sampling frequency varied from 1 to 4 , and the intention was to collect most frequently in January/February, during the most intensive differentiation period. The samples were collected with a WP-2 net with $180 \mu \mathrm{m}$ meshes and a closing mechanism for discrete samples from 200-100 and 100-0 m. On deck the copepods were immediately fixed to a final concentration of $4 \%$ formaldehyde in seawater buffered with hexamine.

The copepodite stages, from $\mathrm{CI}$ to adults, were counted to get a picture of the population dynamics in the period sampled. From each sample we separated 50 Calanus finmarchicus females for prosome measurements and trithek/quadrithek identification. The prosome length was measured using an ocular micrometer with a Wild M5 stereomicroscope at $25 x$ magnification, and the antennules were cut off as close to the cephalothorax as possible. Since mainly the proximal segments were of interest, broken antennules could also be analysed. The antennules were immediately placed on a micro slide with a 1 mm depression and a droplet of filtered seawater. The antennules were identified with a Leitz Labourlux 11 phase contrast microscope as trithek or quadrithek according to definitions and drawings by Fleminger (1985).

The experiment. One hypothesis from Fleminger (1985) proposed that copepod sex change may be under environmental control. We therefore wanted to test experimentally whether the presence of males or females could induce sex change in Calanus finmarchicus (by influence of pheromones). The experiment was designed to allow CVs to moult both in the presence and $a b-$ sence of adult $C$. finmarchicus, and then to count the sex ratio and percentage of quadrithek females.

The experiment consisted of fifteen 10 l beakers which were divided into 3 randomised treatment groups, with males $(M)$, with females (F) and 1 control group (C) with only CVs (Table 1). The treatment groups (1 group per $50 \mathrm{CVs}$ ) consisted of 5 males or females in separate glass cylinders submerged in the $10 \mathrm{l}$ beakers, with both openings covered 
Table 1 Arrangement of the different beakers, nos. 1 to 15 , and their content of CVs, males (M) and females (F). C: control treatment

\begin{tabular}{|c|c|c|c|c|c|c|c|c|c|c|c|c|c|c|c|}
\hline No & 1 & 2 & 3 & 4 & 5 & 6 & 7 & 8 & 9 & 10 & 11 & 12 & 13 & 14 & 15 \\
\hline Treatment & $M$ & $\mathrm{C}$ & $M$ & $C$ & $\mathrm{~F}$ & $\mathrm{~F}$ & M & $\mathrm{C}$ & $F$ & $M$ & $\mathrm{M}$ & $C$ & $\mathrm{~F}$ & $F$ & C \\
\hline $\mathrm{CV}$ & 50 & 50 & 50 & 50 & 50 & 50 & 50 & 50 & 50 & 50 & 50 & 50 & 50 & 50 & 50 \\
\hline Adults & $5 \mathrm{M}$ & & $5 \mathrm{M}$ & & $5 F$ & $5 \mathrm{~F}$ & $5 \mathrm{M}$ & & $5 F$ & $5 \mathrm{M}$ & $5 \mathrm{M}$ & & $5 \mathrm{~F}$ & $5 \mathrm{~F}$ & \\
\hline
\end{tabular}

with plankton net. These copepods were caught in Grotsund weekly as stage CV over a period of $6 \mathrm{wk}$, and forced to moult to adult males and females in the laboratory within approximately $10 \mathrm{~d}$ as illustrated in Fig. 2. This rapid moulting was made possible both by raising the temperature in the lab from $4^{\circ} \mathrm{C}$ (as experienced in situ) to $7^{\circ} \mathrm{C}$, and by incubation in continuous light (Grigg \& Bardwell 1982, Miller \& Grigg 1991) of $8.3 \mu \mathrm{mol} \mathrm{cm} \mathrm{cm}^{-2} \mathrm{~s}^{-1}$. The rest of the CVs were caught $1 \mathrm{~d}$ prior to the start of the experiment, and immediately transferred to the experimental beakers. Because it is believed that food is not necessary to complete maturation (Miller \& Grigg 1991), none of the individuals were fed during the experiment. To ensure that pheromones from the treatment animals came into contact with the CVs, the glass cylinders were moved up and down once a day. The experimental beakers were covered with black plastic to prevent the influence of strong light from the light sources in the room, which did not exceed $8.3 \mu \mathrm{mol} \mathrm{cm}^{-2} \mathrm{~s}^{-1}$. The average temperature in the beakers was $4^{\circ} \mathrm{C}$. To avoid contamination, it was necessary to completely change the water in the 15 beakers 3 times during the experimental period. No increase in mortality was observed as a result of this procedure.

Every second day the water quality was examined visually, and in case of mortality the treatment groups were replaced. CV copepods that died during the experimental period were removed from the beakers

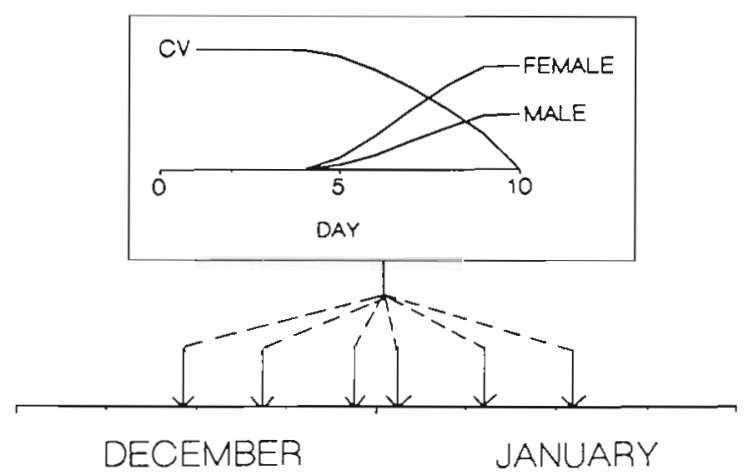

Fig. 2. Calanus finmarchicus. The moulting process in the laboratory. CVs were caught weekly over a period of $6 \mathrm{wk}$, as indicated by arrows. After approximately $10 \mathrm{~d}, 50 \%$ of the CVs had moulted to males and females and fixed with formaldehyde, but not replaced. In the last week of the experiment, the copepods experienced a daylength of approximately $3 \mathrm{~h}$, equivalent to that found in surface waters at Grotsund (at that time of the year, i.e. $0.56 \mu \mathrm{mol} \mathrm{cm}^{-2} \mathrm{~s}^{-1}$ ).

After 1 mo the experiment was terminated, at a time when all the beakers contained a majority of moulted copepods. We made this decision in order to avoid any impact of moulted CV as treatment animals on the still unmoulted copepods. The copepodid stages, sex ratio and trithek/quadrithek females were recorded for each beaker. The statistical tests were carried out after standard procedures as described in Zar (1984).

\section{RESULTS}

\section{Population dynamics}

The standing stock of Calanus finmarchicus differed between the 2 winters investigated (Fig. 3). The stages CI, CII and CIII were, generally, modestly represented in both years, and CIV represented a rather constant proportion of the resting stock. When the number of CV dropped, the number of adult individuals increased. The abundance of males increased from late January onwards, while the females attained maximum abundance in March.

\section{Dispersion of trithek and quadrithek females}

The distribution of quadrithek females was examined from November to April in 1993/1994 and 1994/1995 in Grøtsund. A Pearson chi-squared test revealed no significant difference in frequency of quadrithek females between the 2 depth intervals sampled $\left(\chi^{2}{ }_{1}<\chi^{2} 0.05,1=\right.$ $3.84)$, and the data are therefore merged.

The frequency of quadrithek females (\% Q) followed roughly the same pattern in the 2 years, although monthly variations did occur. A log-linear model (Zar 1984) was utilised to describe the observed pattern of quadritheks (Fig. 4). The model shows that the observed pattern of quadritheks among months is best described as a function of season $\left(\chi^{2}<\chi^{2} 0.05 .5=11.07\right)$. A maximum frequency around $40 \%$ was found in February. 


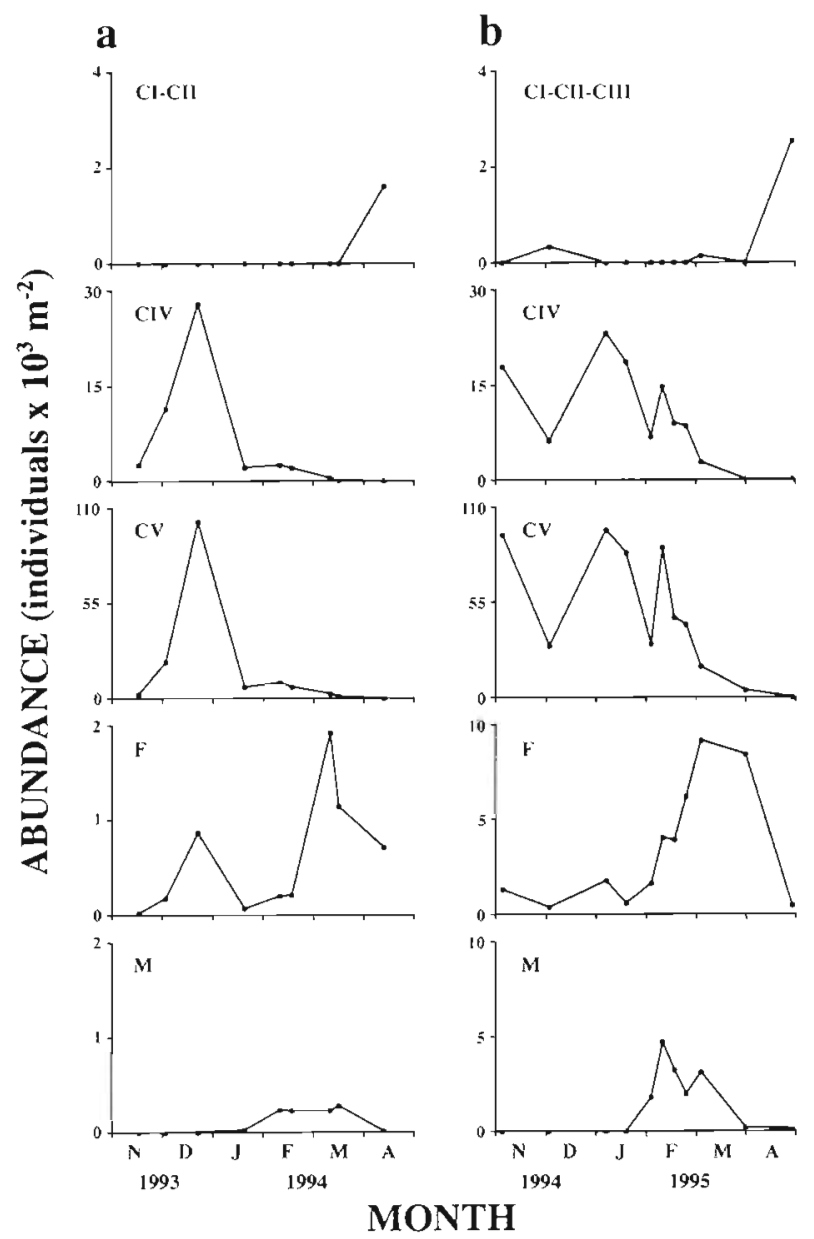

Fig. 3. Calanus finmarchicus. Population abundance and seasonal progression of instars (a) from November 1993 to April 1994 and (b) from November 1994 to April 1995. Note different scales on the $y$-axes

\section{Prosome length}

The prosome length was measured for all females from each sample. Quadrithek females were significantly larger than the tritheks in both depths and periods (Fig 5). The trithek females from 1994/1995 in the depth range 200-100 m were also significantly larger than the tritheks from $0-100 \mathrm{~m}$ depth.

\section{Survival and sex ratio in the experiment}

The antennules of females, both dead and alive, from the experiment were analysed as previously described. The 15 experimental beakers showed no statistically significant trend $\left(\chi^{2}{ }_{1}<\chi_{0.05,1}^{2}=3.84\right)$ between the treatment groups 'male', 'female' or 'control', with overall percentages of 33, 35 and $37 \%$ quadritheks, respectively (Fig. 6). The sex ratio of adults (males,

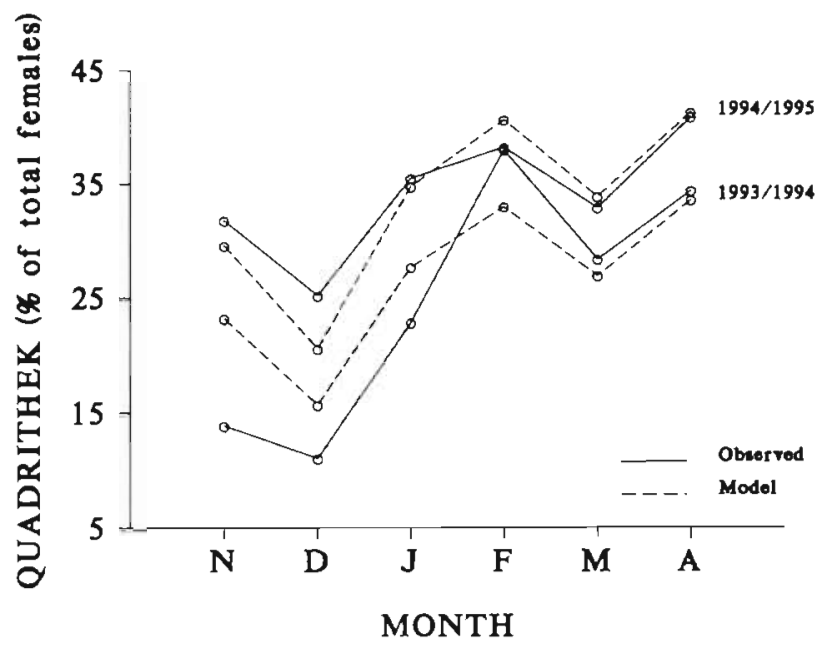

Fig. 4. Calanus finmarchicus observed $(\% \mathrm{Q}=[\mathrm{Q} / \mathrm{Q}+\mathrm{T}] \times 100)$ and modelled distribution of quadrithek females from November 1993 to April 1994 and from November 1994 to April 1995. The observed values represent a mean from 2 to 8 hauls. $N(1993 / 1993)=728, N(1994 / 1995)=1558$. See text for further information

tritheks and quadritheks) did not seem to be influenced by the different treatments, and the mean sex ratio for all the beakers was $14 \%$ males, $55 \%$ tritheks and $31 \%$ quadritheks. It should be noted that the males and quadrithek females constituted $45 \%$ of the total number of adult individuals.

The survival in each of the 15 beakers is presented in Table 2 . A total of $50 \%$ of the individuals moulted from CVs to adults, while $34 \%$ did not. Thirteen percent died as CVs before the experiment was terminated, and approximately $2 \%$ of the initial CVs were lost or could not be identified as male, female or CV, and were placed in a special category (unidentified/lost). This relatively high mortality rate in the experiment was mainly caused by an extreme mortality of unmoulted CVs, $\sim 67 \%$, in beaker no. 1 (male treatment). This was probably due to contamination (the water became white) found in this beaker only.

\section{DISCUSSION}

\section{Population dynamics}

According to previous investigations in Northern Norway, sexual differentiation and gonad maturation take place in January and February (Tande \& Hopkins 1981, Tande 1982) at locations with 1 single generation a year. This was further supported by these investigations from Grotsund. The males entered the population approximately 1 mo prior to the females, corresponding to the knowledge that male Calanus finmarchicus have a shorter development period than females (Mar- 
Fig. 5. Calanus finmarchicus mean prosome length with $95 \%$ confidence interval for trithek (*) and quadrithek females ( $\mathbf{v}$ ) caught from $100-0 \mathrm{~m}$ and $200-100 \mathrm{~m}$ in $1993 / 1994$ and $1994 /$ 1995. The number next to each symbol indicates the number of individuals at each point. Total number of animals examined is 2286
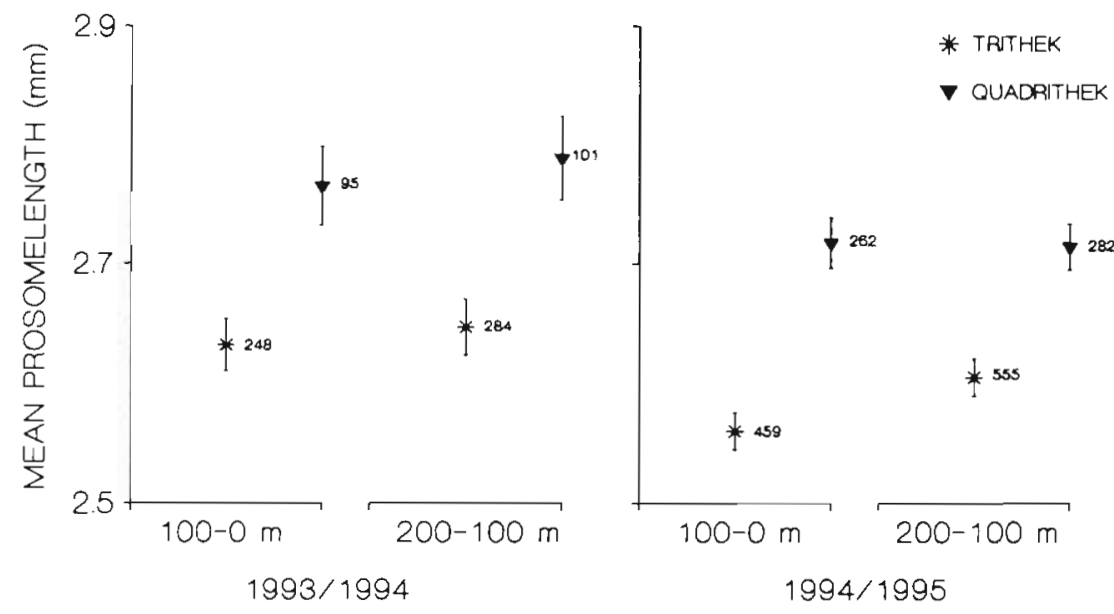

shall \& Orr 1972). The peak of males was found in February, but the sex ratio was heavily biased towards females both before and after this period. The standing stock of adults was different between the 2 years, but a heterogeneous distribution in the water column may be caused by biological and hydrodynamical factors (Stavn 1971, Dagg 1977, Longhurst 1981, Kiørboe 1988, George 1989, Giske 1990). Therefore, this may not necessarily reflect actual differences in adult population size (see also Fig. 3).

\section{Prosome length}

In Grøtsund the quadritheks had significantly larger prosomes than the tritheks. Corresponding measurements from Georges Bank (USA) also revealed a general tendency for quadrithek females to be Iarger, although this was only significant in 4 out of 6 mo (C. Miller pers. comm.). Fleminger (1985), however, found no relation between prosome length and dimorphism in Calanus pacificus californicus. It has been demonstrated that CV males about to develop testes are larger than CV females with unripe ovaries (Grigg et al. 1981, 1985, Miller et al. 1991), and that there is a substantial growth increment from CV to adult for females but not for males. Ghiselin $(1969,1974)$ formulated a 'size-advantage model', claiming that 'if a small or young animal can reproduce more effectively as a member of one sex, while a large or older animal can

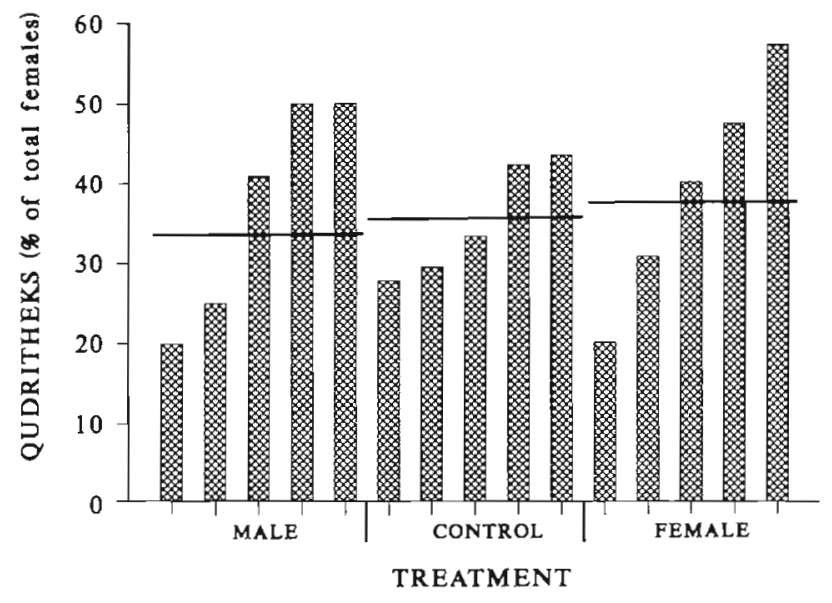

Fig. 6. Calanus finmarchicus percentage distribution of quadrithek females in each experimental beaker. The horizontal line indicates the average value of quadritheks in each treatment group

Table 2. Calanus finmarchicus. Distribution of adult females, males, alive and dead CVs and unidentified individuals in each experimental beaker. The number of females and males includes both the living animals at the end of the experiment and the ones that died before the termination. Treatment $\mathrm{M}, \mathrm{F}$ or $\mathrm{C}$ indicates treatment with males, females or only control. Note the low survival in beaker 1

\begin{tabular}{|c|c|c|c|c|c|c|c|c|c|c|c|c|c|c|c|}
\hline \multirow{2}{*}{$\begin{array}{r}\text { Treatment: } \\
\text { No: }\end{array}$} & \multicolumn{5}{|c|}{$M$} & \multicolumn{5}{|c|}{$F$} & \multicolumn{5}{|c|}{$\mathrm{C}$} \\
\hline & 1 & 2 & 3 & 4 & 5 & 1 & 2 & 3 & 4 & 5 & 1 & 2 & 3 & 4 & 5 \\
\hline Female & 4 & 16 & 22 & 20 & 28 & 26 & 25 & 21 & 19 & 30 & 18 & 18 & 34 & 23 & 26 \\
\hline Male & 0 & 6 & 2 & 4 & 2 & 4 & 4 & 3 & 3 & 5 & 3 & 5 & 4 & 1 & 6 \\
\hline CV alive & 8 & 21 & 17 & 16 & 18 & 17 & 18 & 20 & 24 & 14 & 19 & 18 & 11 & 22 & 9 \\
\hline CV dead & 33 & 7 & 8 & 9 & 2 & 2 & 3 & 6 & 3 & 1 & 8 & 5 & 1 & 4 & 8 \\
\hline Unidentified or lost & 5 & 0 & 1 & 1 & 0 & 1 & 0 & 0 & 1 & 0 & 2 & 4 & 0 & 0 & 1 \\
\hline
\end{tabular}


Table 3. Calanus sp. Percentage distribution (in whole numbers) of quadrithek females in the Inland Sea of Japan ( $N=3082$ ), at Point Conception (USA) ( $N=1085$ ), and in Grotsund (Norway) ( $N=2286$ ) and the Greenland Sea ( $N=171$ ). Lat.: latitude; Gen.: number of generations

\begin{tabular}{|lclccccccc}
\hline Locality & Lat. & Species & Gen. & Jan & Feb & Mar & Apr & May & Source \\
\hline Inland Sea of Japan & $34^{\circ} \mathrm{N}$ & C. sinicus & Cont. & 4 & - & - & 4 & - & Uye (unpubl.) \\
Point Conception & $34^{\circ} \mathrm{N}$ & C. pacificus Californicus & Cont. & 11 & 11 & - & 10 & 7 & Fleminger (1985) \\
Grotsund (1994) & $69^{\circ} \mathrm{N}$ & C. finmarchicus & 1 & 23 & 38 & 28 & 34 & - & Present paper \\
Grotsund (1995) & $69^{\circ} \mathrm{N}$ & C. finmarchicus & 1 & 36 & 39 & 33 & 41 & - & Present paper \\
Greenland Sea & $78^{\circ} \mathrm{N}$ & C. finmarchicus & $>1-1$ & - & 19 & 38 & 27 & - & Hirche (unpubl.) \\
\hline
\end{tabular}

reproduce more easily as a member of the other sex, then it becomes advantageous for an individual to change sex as it grows older. Where it is advantageous for a male to be large or a female to be small, protogyny should evolve'. This means that a sex change is expected when the reproductive output of the opposite sex is larger (Warner 1988).

The correlation between large female body size and reproductive success is described for calanoid copepods (Corkett \& McLaren 1969, 1978, Durbin et al. 1983. Maly 1983), marine invertebrates in general (Petraitis 1990) and especially for Calanus finmarchicus (Runge \& Plourde 1996). However, the body size of the male is less related to reproductive success (Fleminger 1985). The ovary development and fecundity of the female are expected to vary directly with the size or volume of the prosome (McLaren 1965), but the amount of food available can also affect fecundity (Paffenhöfer 1970, Marshall \& Orr 1972, Paffenhöfer \& Harris 1976, Heinle et al. 1977, Gatten et al. 1980). Protandric sex change in marine invertebrates is thus thought to be tightly linked to the dependence of female fecundity and body size, given a random mating system (Petratis 1990). Ghiselin's model has been appraised for sex change in fish (Warner 1988), but if it is also relevant for Calanus finmarchicus, it will be an advantage for $\mathrm{CV}$ males to change sex, because they probably will end up larger than average females.

\section{Distribution of quadrithek females}

Significant differences in quadrithek abundance between the 2 time series in Grøtsund were only found in November and December, and according to a loglinear model, the observed dynamics of quadritheks can largely be explained as a function of season. The low percentage of quadrithek females in November and December is most likely due to individuals that returned to rest in May or June the preceding spring At that time, almost all females young enough to return to rest will be genetically normal females. Peaks of males and quadrithek females co-occurred in Febru- ary, which could result from both males and quadrithek females maturing at the same time in the resting stock. The decrease in the fraction of quadritheks in March could result from depletion of the stock of genetic male CVs supplying new quadrithek females, coupled with increasing maturation rates of genetic female CVs as trithek females.

Compared to other locations, the population of Calanus finmarchicus in Northern Norway had a high proportion of quadrithek females. Around Georges Bank $\left(\sim 41^{\circ} \mathrm{N}\right)$, where C. finmarchicus may have 2 or 3 generations $\mathrm{yr}^{-1}, 16$ and $6 \%$ of quadrithek females has been reported for the first and second generation, respectively (J. Crain \& C. Miller unpubl, data). Further south, in the Inland Sea of Japan, a population of C. sinicus was found to consist of only 4 to $6 \%$ quadrithek females (Uye unpubl.), and Fleminger (1985) found the proportion of C. pacificus californicus quadritheks to vary from 11 to $7 \%$. C. sinicus (Huang et al. 1993) have a continuous reproduction cycle and do not go into diapause, whereas a proportion of $C$. pacificus californicus does rest at these latitudes. However, in C. finmarchicus from the Greenland Sea, with a supposed annual generation (McLelland 1967. Hirche 1991), a proportion of $38 \%$ quadritheks was found in March, similar to observations in North Norwegian fjords.

It is obvious that within the same genus (Calanus) the same phenomenon (female dimorphism) occurs in different proportions in various habitats (Point Conception, Georges Bank, the Inland Sea of Japan, Grotsund and the Greenland Sea). It seems as if the fraction of quadritheks increases with increasing latitude (Table 3), i.e. that the dimorphism is more frequent at locations where the species have 1 generation a year compared to habitats with several generations. In order to state the case more concisely, we have outlined a conceptual model for some of the observed phases during the period of reproduction in Calanus (Fig. 7). Although we do not know at which stage in the life cycle the genotypic sex is determined, it could occur within the time period from embryo until well into $\mathrm{CV}$. During the sexual differentiation period, CVs 
proceed rapidly through a short period as phenotypical males and females. This has been described in detail by, for instance, Tande \& Hopkins (1981). We believe that a signal to form the male aesthetascs pattern must exist, and that the quadrithek pattern is a result of this signal occurring before sex differentiation. However, we do not know whether this potential signal can occur later than 'the signal' for sex differentiation, resulting in an ordinary trithek pattern on the antennules (C. Miller pers. comm.). The present study substantiates the following 2 pieces of knowledge: firstly, there are indications for a sex change where genetic males turn into quadrithek females, and secondly, the magnitude of this process varies latitudinally (i.e. inversely related to the number of generations produced).

Based on the results above, we can ask the following question: Why are different life history parameters correlated to latitude in calanoid copepods? This phenomenon is, to our knowledge, not previously described for calanoid copepods, but a similar case has been reported for the amphipod Gammarus dubeini (Watt \& Adams 1993a, b, 1994). The authors found a broad correlation between latitude (and breeding seasonality) and the strength of the environmental sex determination (ESD) response across a series of population studies. In this case, it is believed that sex determination is correlated to photoperiod, and is probably an adaptive response to seasonal population dynamics (Watt \& Adams 1993a, b, 1994). To some extent, this is also the case for the protandric hermaphrodite Pandalus borealis. Generally, there is a tendency for shrimp populations to show an increased lifespan and lower growth rate at higher latitudes (Charnov 1982), and Rasmussen $(1953,1969)$ was the first to show that the life history variables of $P$. borealis changed with latitude in Northern Europe (58 to $78^{\circ} \mathrm{N}$ ). He showed that the time spent as a male (i.e. the time before the sex change) increased from $>1$ to fully $2 \mathrm{yr}$, and explains this not as a function of photoperiod, but of temperature.

A different mechanism of sex change is found in the polychaete Capitella capitata (species type I) (Petraitis 1990). The natural population contains males, females and hermaphrodites, where a heterogametic system (genotype $Z W$ ) always expresses females, and a homogametic system (genotype ZZ) expresses labile determination of genders. Homogametic individuals (ZZ) are initially males when raised en masse, but can become hermaphrodites if fe- males are rare. It is suggested that mate competition and the strong correlation between fecundity and body size are major forces for the evolution of protandry in marine invertebrates. The cost of changing sex from male to female (or hermaphrodite) is in the case of $C$. capitata balanced by the increased reproductive success caused by an enlarged body size (Petraitis 1990); this could also be the case for other marine invertebrates such as Calanus.

It has previously been suggested that sex change in Calanus is influenced by demographic factors related to the life history strategy of the specific species (Conover 1988). We suggest that the different proportions of sex changing individuals (quadritheks) in northern and southern waters are a reflection of different life history strategies directly or indirectly caused by the number of generations the species is allowed to complete in its habitat. The 'award' to the sex changing individuals is a higher reproductive output (they are few and larger than the genetic females) during a narrow time window when males are found to be in majority.

\section{Sex ratio in the experiment}

Within sexually breeding populations, both parents have identical contributions to the next generation (Fisher 1930, Williams 1974), and due to natural selection the expected sex ratio is 1.00 or $50 \%$ males and females. Therefore, the sex ratio in copepods is ex-

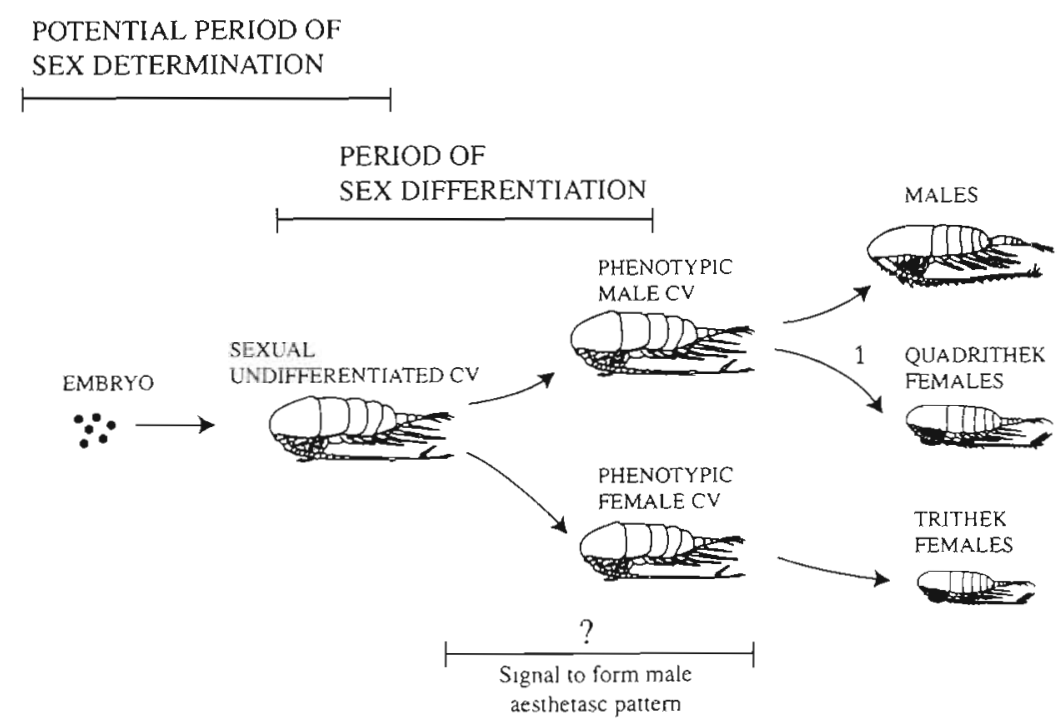

Fig. 7. Conceptual model for some of the observed reproductive phases in Calanus. There are uncertainties connected to the period of sex determination, as it could occur within the time period from embryo until well into CV. The 'signal to form the male pattern of aesthetascs' is hypothetical and could in theory occur both before and after the initiation of a sex change. Symbol: 1 indicates that the sex change frequency varies between habitats 
pected to be 1.00 , although natural populations are known to be dominated by females (Marshall \& Orr 1972, Fulton 1973, Tande \& Hopkins 1981). In the present experiment, the female:male sex ratio was found to be 6.34 , which did not match the expectation. This dominance of females was found in the sexually mature stage and consisted of both trithek and quadrithek. However, if the quadritheks are classified as genetic males, the sex ratio in the same experiment is 1.26 . It is possible to calculate whether this sex ratio is statistically within the $50 \%$ expectation

(males + quadritheks)/(males + quadritheks + trithek $)=0.4424$ $(52+117) /(52+117+213)=0.4424$

For the total sample size, $\mathrm{N}=382$, the $95 \%$ binomial confidence limits (Dixon \& Massey 1957) around this estimate are 0.39 to 0.49 , which do not quite include 0.5 . Nevertheless, including quadrithek females with males brings the observed ratio close to that expected by Fisher's theory.

\section{Does environmental sex determination (ESD) occur in Calanus?}

ESD is defined as a mechanism where the zygote develops as a male or a female mainly as a consequence of environmental conditions (Bull 1983). The first accepted case of ESD was discovered in the marine echiurid worm Bonellia viridis (Baltzer 1912), where almost all larvae develop as females when settled in isolation, and develop as males when exposed to females. Later ESD was reported in several groups of animals (for examples see Bull 1983, 1987). The opposite of ESD, genetic sex determination (GSD) is usually connected to heterogamy where the sex of the zygote is determined independently of the environment. However, a partial capacity for ESD has been observed in several GSD systems (Bull 1983).

Conclusions drawn both from field and experimental studies indicate that the environment may influence sex determination in copepods (Cattley 1948, Takeda 1950, Egami 1951, Mednukov 1961, İgarashı 1964a, b, Monakov 1965, Vaquier \& Belser 1965, Katona 1970, Grigg et al. 1981, 1985, Hopkins 1982). These authors have suggested factors like nutrition, temperature, pressure, population density and parasitism as possible inducers. For crustacea in general, it is also supposed that factors like daylength (Naylor et al 1988a, b, Dunn et al. 1993, Watt 1994, Watt \& Adams 1994), pH, carbon dioxide, UV light, metabolic products and exposure to the opposite sex (Korperlainen 1990, Kawasaki 1995) can influence the sex determination.

Is it realistic to suppose that ESD occurs in Calanus finmarchicus? And when is ESD expected instead of
GSD? Selection for ESD is expected when the offspring enters an environment with a patchy distribution of resources (with respect to local mate competition, resources and predator abundance) and where one sex has an advantage. Sex determination late in the lifecycle is also expected if parents and offspring do not control or choose their future environment (Charnov \& Bull 1977, Bull 1983). In the search for understanding how individual sex is determined in C. finmarchicus, the possible influence of the environment should not be overlooked.

Acknowledgements. We thank Charles Miller for encouraging us to do this investigation, for his valuable comments on the manuscript, and the crew at FF 'Hyas' and FF 'Ottar' for assistance in sample collection. This paper is a contribution to the Trans-Atlantic Study of Calanus finmarchicus (TASC) supported in part by the European Commission (DG XII) contract no. MAST-CT-0039

\section{LITERATURE CITED}

Baltzer F (1912) Über die Entwicklungsgeschichte von Bonellia. Verh Dt Zool Ges 22:252-261

Bull JJ (1983) Evolution of sex determining mechanisms. Benjamin Cummings publishing company, Menlo Park, CA

Bull JJ (1987) Sex determining mechanisms: an evolutionary perspective. In: Stearns SC (ed) The evolution of sex and its consequences. Birkhäuse Verlag, Basel. p 93-114

Cattley JG (1948) Sex reversal in copepods. Nature 161:937

Charniaux-Cotton H (1960) Sex determination. In: Waterman TH. (ed) The physiology of Crustacea. Acad Press, New York, p 411-447

Charniaux-Cotton H (1962) Androgenic gland of Crustaceans. Gen Comp Endocrinol Suppl 1:241-247

Charnov EL (1982) The theory of sex allocation. Princeton University Press, Princeton, NJ

Charnov EL, Bull JJ (1977) When is sex environmentally determined? Nature 266:828-830

Conover RJ (1988) Comparative life histories in the genera Calanus and Neocalanus in high latitudes of the northern hemisphere. Hydrobiologia 167/168:127-142

Corkett CJ, McLaren IA (1969) Egg production and oil storage by the copepod Pseudocalanus in the laboratory. J Exp Mar Biol Ecol 3:90-105

Corkett CJ, McLaren IA (1978) The biology of Pseudocalanus. Adv Mar Biol 15:1-231

Dagg $M$ (1977) Some effects on patchy food environment on copepods. Limnol Oceanogr 22:99-107

Dixon WJ, Massey FJ Jr (1957) Introduction to statistical analysis, 2nd edn. McGraw-Hill Book Company, Inc, New York

Dunn AM, Adams J, Smith JE (1993) Is intersexuality a cost of environmental sex determination in Gammarus dubeini. J Evol Biol 7:177-187

Durbin EG, Durbin AC, Smayda TJ, Verity PG (1983) Food limitation of production by adult Acartia tonsa in Narragansett Bay, Rhode Island. Limnol Oceanogr 28:1199-1213

Egami N (1951) A note on the sex-differentiation of the marine copepod Tigriopus japonicus. Annot Zool Jpn. 24:131-136

Fisher RA (1930) The genetical theory of natural selection. Clarendon Press, Oxford

Fleminger A (1985) Dimorphism and sex change in copepods of the family Calanidae. Mar Biol 88:273-294 
Fulton J (1973) Some aspects of the life history of Calanus plumchrus in the Strait of Georgia. J Fish Res Bd Can 30: $811-815$

Gatten RR, Sargent JR, Forsberg TEV, O'Hara SCM, Corner EDS (1980) On the nutrition and metabolism of zooplankton. XIV Utilization of lipid by Calanus helgolandicus during maturation and reproduction. J Mar Biol Assoc UK 60: 391-399

George DG (1989) Zooplankton patchiness in enclosed and unenclosed areas of water. J Plankton Res 11:173-184

Ghiselin MT (1969) The evolution of hermaphroditism among animals. Q Rev Biol 44:189-208

Ghiselin MT (1974) The economy of nature and the evolution of sex. University of California Press

Giske J (1990) Vertical distribution and trophic interactions of zooplankton and fish in Masfjorden, Norway. In: Habitat profitability in the pelagic environment. PhD thesis

Grigg H, Bardwell SJ (1982) Seasonal observations on moulting and maturation in stage $V$ copepodites of Calanus finmarchicus from the Firth of Clyde. J Mar Biol Assoc UK 62: 315-327

Grigg H, Bardwell SJ, Tyzack S (1981) Pattern of variation in the prosome length of overwintering stage $V$ copepodites of Calanus finmarchicus in the Firth of Clyde. J Mar Biol Assoc UK 61:885-899

Grigg H, Holmes LJ, Bardwell SJ (1985) Seasonal observations on the biometry and development in copepodite stage $\mathrm{V}$ of Calanus finmarchicus from the Firth of Clyde. Mar Biol 88:73-83

Heinle DR, Harris RP, Ustach J, Flemer DA (1977) Detritus as food for estuarine copepods. Mar Biol 40:341-353

Hirche HJ (1991) Distribution of dominant calanoid copepod species in the Cireenland Sea during late fall. Polar Biol 11. $351-362$

Hopkins C (1982) The breeding biology of Euchaeta norvegica (Boeck) (Copepoda: Calanoida) in Loch Etive, Scotland: assessment of breeding intensity in terms of seasonal cycles in the sex-ratio, spermatophore attachment and egg-sac production. J Exp Mar Biol Ecol 60:91-102

Huang C, Uye S, Onbé T (1993) Geographic distribution, seasonal life cycle, biomass and production of a planktonic copepod Calanus sinicus in the Inland Sea of Japan and its neighboring Pacific Ocean. J Plankton Res 15:1229-1246

Igarashi S (1964a) A possibility of cytoplasmic inheritance of the male dominancy in Tigriopus japonicus. Sci Rep Tohoku Univ Ser IV (Biol) 30:77-84

Igarashi S (1964b) Modification of sex-ratio by feeding the ovisacs in Tigriopus japonicus. Sci Rep Tohoku Univ Ser IV (Biol) 30:85-88

Katona SK (1970) Growth caracteristics of the copepods Eurytemora affinis and herdmani in laboratory cultures. Helgoländer Wiss Meeresunters 20:373-384

Kawasaki $N$ (1995) Sex determining pheromone of poecilostomatoid copepod, Pseudomyicola spinosus (Raffaele and Monticelli), associated with bivalves. BEng thesis, Soka University, Tokyo

Kiørboe T (1988) Planktonfødekæden: bioenergetiske og økologiske studier. Danmarks Fiskeri- og havundersøgelser

Korpelainen H (1990) Sex ratios and conditions required for environmental sex determination in animals. Biol Rev 65 $147-184$

Longhurst AR (1981) Significance of spatial variability. In Longhurst AR (ed) Analyses of marine ecosystems. Acad Press, London, p 415-441

Maly EJ (1983) Some further observations on diaptomid body size and clutch size relationships. Limnol Oceanogr 28 : $148-152$
Marshall SM, Orr AP (1972) The biology of a marine copepod Calanus finmarchicus (Gunnerus). Oliver and Boyd, Edinburgh

McLaren I (1965) Some relationships between temperature and egg size, body size, development rate and fecundity, of the copepod Pseudocalanus. Limnol Oceanogr 10: $528-538$

McLellan D (1967) The annual cycle of certain calanoid species in West Greenland. Can J Zool 45:101-115

Mednikov BM (1961) On the sex ratio in deep water calanoida. Crustaceanâ 3:105-109

Miller CB, Cowles TJ, Wiebe PH, Copley NJ, Grigg H (1991) Phenology in Calanus finmarchicus; hypotheses about control mechanisms. Mar Ecol Prog Ser 72:79-91

Miller CB, Brigg H (1991) An experimental study of the resting phase in Calanus finmarchicus (Gunnerus). Proceedings of the Fourth International Conference on Copepoda. Bull Plankton Soc Jpn Spec Vol:497-493

Monakov AV (1965) Influence de la température sur la sex ratios dans la descendance de Macrocyclops albidus (Copepoda: Crustacea). Zool Zh 44:606-608

Naylor C, Adams J, Greenwood PJ (1988a) Variation in sex determination in natural populations of a shrimp. $J$ Evol Biol 1:355-368

Naylor C, Adams J, Greenwood PJ (1988b) Population dynamics and adaptive sexual strategies in a brackish water crustacean, Gammarus dubeni. J Anim Ecol 57: 493-507

Paffenhöfer GA (1970) Cultivation of Calanus helgolandicus under controlled conditions. Helgoländer Wiss Meeresunters 20:346-359

Paffenhöfer GA, Harris RP (1976) Feeding growth and reproduction of the marine planctonic copepod Pseudocalanus elongatus Boeck. J Mar Biol Assoc UK 56:327-344

Petraitis PS (1990) Dynamics of sex change in a capitellid polychaete. In: Mangel M (ed) Some mathematical questions in biology, sex allocation and sex change: experiments and models. The Mathematical Society, Providence, RI, p $127-154$

Rasmussen $B$ (1953) On the geographical variation in growth and sexual development of the deep sea prawn (Pandalus borealis). Rep Norw Fish Mar Invest 10:160

Rasmussen B (1969) Variations in protandric hermaphroditism in Pandalus borealis. FAO Fish Rep 57:1102-1106

Runge JA, Plourde S (1996) Fecundity characteristics of Calanus finmarchicus in coastal waters of eastern Canada. Ophelia 44:171-187

Stavn RH (1971) The horizontal-vertical distribution hypothesis: Langmuir circulation and Daphnia distribution. Limnol Oceanogr 16:453-466

Takeda N (1950) Experimental studies on the effect of external agencies on the sexuality of a marine copepod. Physiol Zool 23:288--301

Tande KS (1982) Ecological investigations of the zooplankton community of Balsfjorden, Northern Norway: generation cycles, and variations in body weight and body content of carbon and nitrogen related to overwintering and reproduction in the copepod Calanus finmarchicus (Gunnerus) J Exp Mar Biol Ecol 62:129-142

Tande KS, Hopkins CCE (1981) Ecological investigations of the zooplankton community of Balsfjorden, Northern Norway: the genital system in Calanus finmarchicus and the role of gonad development in overwintering strategy. Mar Biol 63:159-164

Vacquier VD, Belser WD (1965) Sex conversion induced by hydrostatic pressure in the marine copepod Tigriopus californicus. Science 150:1619-1621 
Warner RR (1988) Sex change in fishes: hypotheses, evidence, and objections. Environ Biol Fish 22:81-90

Watt P (1994) Parental control of sex ratio in Gammarus duebeni, an organism with environmental sex determination. J Evol Biol 7:177-187

Watt P, Adams J (1993a) Adaptive sex determination and population dynamics in a brackish-water amphipod. Estuar Coast Shelf Sci 37:237-250

Watt P, Adams J (1993b) Adaptive sex determination and

Editorial responsibility: Thomas Kiorboe, Charlottenlund, Denmark population dynamics in a brackish-water amphipod. Estuar Coast Shelf Sci 37:237-250

Watt P, Adams J (1994) Adaptive variation in sex determination in a crustacean, Gammarus dubeni. J Zool 232:109-116

Williams GC (1974) Adaptation and natural selection: a critique of some current evolutionary thought. Princeton University Press, Princeton, NJ

Zar JH (1984) Biostatistical analysis, 2nd edn. Prentice Hall, Englewood Cliffs, $\mathrm{NJ}$

Submitted: January 20, 1998; Accepted: September 9, 1998 Proofs received from author(s): January 12, 1999 